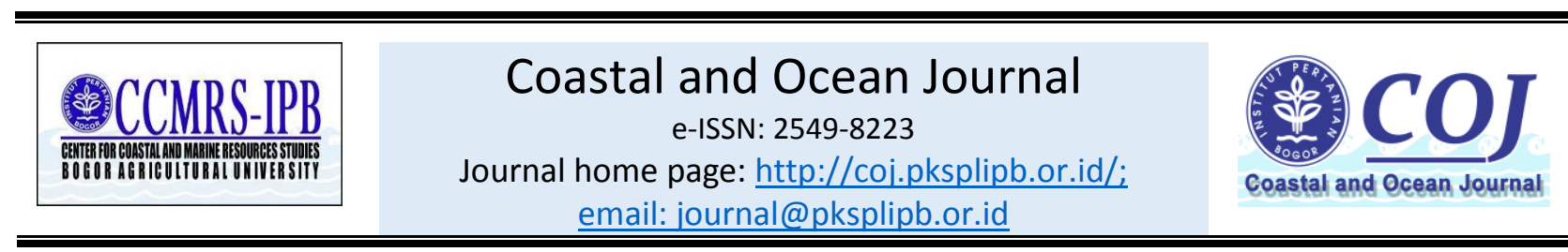 \\ KONSEP KONSERVASI BERBASIS KAWASAN DALAM RANGKA PEMULIHAN POPULASI ENDEMIK BANGGAI CARDINALFISH (Pterapogon kauderni)
}

\section{A SITE-BASED CONSERVATION APPROACH TO PROMOTE THE RECOVERY OF BANGGAI CARDINALFISH (Pterapogon kauderni) ENDEMIC POPULATIONS}

\author{
Abigail Mary Moore a, Samliok Ndobe ${ }^{b}$, Jamaluddin Jompa ${ }^{*}$ \\ a Program Studi S3 Ilmu Perikanan, Fakultas Kelautan dan Perikanan, Universitas Hasanuddin. \\ b Program Studi Akuakultur, Fakultas Peternakan dan Perikanan, Universitas Tadulako \\ c Fakultas Ilmu Kelautan dan Perikanan, Universitas Hasanuddin \\ *E-mail: j.jompa@unhas.ac.id
}

\begin{abstract}
The endemic Banggai cardinalfish (Pterapogon kauderni) is an Indonesian conservation priority with Endangered species. The goal of this research was to develop a site-based conservation concept appropriate from a bio-ecological viewpoint, based on the unusual characteristics of this species, in particular: (i) mouthbrooder with direct development, leading to reproductively isolated stocks and fine scale genetic structure; (ii) high level of reliance on habitat, in particular symbiosis with benthic animals providing protective micro-habitat. Methods used include review and analysis of published literature and unpublished data, including an analysis using the Marxan spatial planning software. We suggest several policy options and

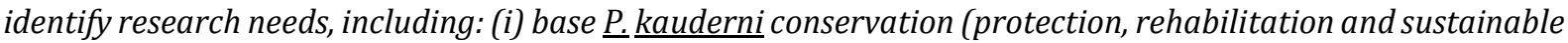
use) on stocks as the basic management unit; (ii) use data on P. kauderni genetic stocks in the zonation of the proposed Banggai Archipelago marine protected area (MPA); (iii) undertake further research to identify stocks/stock boundaries; (iv) apply the "BCF gardens" concept to fine-scale rebuilding of $\underline{\text {. }}$ kauderni populations and enabling sustainable use through micro-habitat rehabilitation, with a community-based approach supported by a multi-phase scientific research program. The outputs from this study should support efforts towards sustainable management of the Banggai cardinalfish, particularly in the context of strategies to develop and manage an effective sub-national MPA.
\end{abstract}

Keywords: genetic stock; habitat/micro-habitat rehabilitation; community-based conservation; marine protected area; Marxan

\section{ABSTRAK}

Salah satu spesies prioritas konservasi di Indonesia adalah ikan endemik Banggai cardinalfish (Pterapogon kauderni) dengan status terancam punah. Penelitian bertujuan mengembangkan suatu konsep konservasi berbasis kawasan yang tepat secara bioekologi, didasarkan pada sifat bioekologis khas ikan tersebut, antara lain: (i) telur dierami hingga menetas lalu berkembang dalam mulut ikan jantan sampai fase larva berakhir; hal ini menyebabkan stok-stok terisolasi secara reproduktif dan memiliki sifat genetik khas; (ii) ketergantungan tinggi terhadap habitat, khususnya simbiosisnya dengan organisme yang berperan sebagai mikro-habitat pelindung. Metode yang digunakan adalah review dan kajian terhadap literatur ilmiah maupun data yang belum terpublikasi, termasuk hasil analisa dengan menggunakan software Marxan. Hasil mencakup sejumlah rekomendasi kebijakan maupun penelitian lanjutan, antara lain: (i) konservasi (perlindungan, pemulihan dan pemanfaatan berkelanjutan) P. kauderni dilakukan berbasis sub-unit populasi (stok); (ii) data stok genetik P. kauderni menjadi salah satu dasar zonasi Kawasan Konservasi Perairan Daerah (KKPD) di Kepulauan Banggai; (iii) penelitian dilaksanakan untuk melanjutkan identifikasi stok genetik dan batas-batas diantarantya; (iii) ditawarkan konsep "BCF gardens", yaitu sebuah pola pemulihan dan pemanfaatan berkelanjutan populasi P. kauderni melalui pemulihan mikrohabitat, dilaksanakan pada skala kecil, berbasis masyarakat, dan didukung oleh program riset ilmiah secara bertahap. Hasil kajian ini diharapkan sebagai sumbangan informasi pengelolaan berkelanjutan P. kauderni, khususnya dalam konteks strategi pengembangan dan pengelolaan KKPD yang efektif.

Kata kunci: stok genetik; pemulihan habitat/mikro-habitat; konservasi berbasis masyarakat; kawasan konservasi perairan; Marxan 


\section{PENDAHULUAN}

Banggai cardinalfish (Pterapogon kauderni, Koumans 1933), ikan dari Famili Apogonidae, memiliki penyebaran alami (endemik) sangat terbatas, dengan luasan total habitat sekitar $30 \mathrm{~km}^{2}$ di perairan dangkal (kedalaman < 5m) 34 pulau, umumnya di Kepulauan Banggai, Sulawesi Tengah, Indonesia (Vagelli, 2011). Setelah penemuan ulang oleh pakar iktiologi Gerry Allen tahun 1994, P. kauderni menjadi primadona penggemar ikan hias laut; lima tahun kemudian, $P$. kauderni telah dianggap terancam punah (Allen, 2000). Analisa dinamika populasi menunjukkan laju pemanfaatan $(E=0,5)$ tergolong tinggi (Ndobe dkk., 2013a). Kajian yang menghasilkan status Endangered (terancam punah) pada Red List IUCN (International Union for the Conservation of Nature) menyebutkan dua ancaman utama terhadap populasi endemik P. kauderni, yaitu pemanfaatan sebagai ikan hias dan degradasi/kehilangan habitat (Allen \& Donaldson, 2007).

Pada Famili Apogonidae, telur yang telah dibuahi dierami dalam mulut induk jantan lalu berkembang dalam mulutnya hingga menetas, namun induk jantan $P$. kauderni tetap mengerami hingga fase larva berakhir (Vagelli, 2011). Tanpa fase pelagis, P. kauderni tidak berpindah jauh sepanjang daur hidupnya, maka apabila terjadi kepunahan lokal (ekstirpasi), pemulihan alami hampir tidak mungkin ataupun mustahil (Kolm dkk., 2005; Vagelli, 2011; Moore dkk., 2012; Ndobe dkk., 2013b). Daur hidup tersebut mengakibatkan pula struktur genetik populasi pada skala sangat kecil; dengan sejumlah besar stok terpisah secara reproduktif yang memiliki genetika khas, ekstirpasi akan mengakibatkan kepunahan strain genetik (Hoffman dkk., 2005; Vagelii dkk., 2009; Ndobe, 2013).

Simbiosis P. kauderni dengan biota yang berperan sebagai mikrohabitatnya, terutama bulubabi (Diadema sp.), anemone laut termasuk Actinodendron sp., Entacmea quadricolor, Heteractis crispa, $H$. magnifica, H. malu, Stichodactyla gigantea, dan karang keras, terutama koloni dengan bentuk bercabang (Vagelli, 2004; Ndobe dkk., 2008; Ndobe, 2013; Moore dkk., 2017), dipandang sebagai faktor penentu dalam keberhasilan reproduksi dan dinamika populasi $P$. kauderni di alam (Moore dkk., 2012; Vagelli, 2011; Ndobe, 2013; Ndobe dkk., 2013a,b,c,d,e; Talbot dkk., 2013); lebih lanjut, data empirik menunjukan bahwa pelestarian dan (apabila telah terdegradasi) pemulihan mikrohabitat (simbion) sebagai kondisi mutlak keberhasilan pelestarian populasi $P$. kauderni, khususnya di wilayah penyebaran endemiknya (Moore dkk., 2012; Ndobe, 2013; Ndobe dkk., 2013b,c).

Kelestarian P. kauderni menjadi isu nasional dan internasional ketika $P$. kauderni didaftarkan pada Lampiran II CITES (Convention on International Trade in Endangered Species of Wild Fauna and Flora) diusulkan untuk pertama kali pada pertemuan CoP (Conference of the Parties) CITES ke-14 tahun 2007. Rencana Aksi Nasional Banggai Cardinalfish (RAN-BCF) 2007-2012 tersusun pasca CoP CITES ke14, dan P. kauderni ditetapkan sebagai biota perairan prioritas konservasi di Indonesia periode 2009-2014 maupun 2015-2019. Berbagai upaya yang dilakukan belum menghasilkan kerangka kebijakan atau sistem yang efektif untuk menjamin kelestarian populasi endemik ikan tersebut saat $P$. kauderni didaftarkan pada Lampiran II CITES kembali diusulkan pada CoP CITES ke-17 tahun 2016. Hasil pertemuan tersebut, Indonesia membuat komitmen lagi untuk menjamin kelestarian P. kauderni, dan diwajibkan untuk melaporkan progress pada pertemuan Komisi Hewan CITES yang direncanakan pada bulan Juli tahun 2018. 
Dalam konteks RAN-BCF 2007-2012, P. kauderni ditetapkan sebagai sasaran konservasi (pada dua diantara sepuluh pulau) di Kawasan Konservasi Laut Daerah (KKLD) yang dicanangkan melalui SK Bupati Banggai Kepuluan No. 540 Tahun 2007. Cakupan KKLD tersebut dinilai lemah dari aspek konservasi populasi, habitat dan keanekaragaman genetik $P$. kauderni (Ndobe dkk., 2012). Sebelum efektif diterapkan KKPD tersebut, terjadi pemekaran Kabupaten Banggai Laut, mencakup bagian selatan dari kabupaten induk (Kabupaten Banggai Kepulauan) pada tahun 2013; kemudian kewenangan untuk konservasi perairan berubah dengan disahkan Undang-Undang Otonomi Daerah baru (UU 23/2014). Aspek positif dari perubahan-perubahan tersebut adalah peluang untuk mereview konsep KKPD di Kepulauan Banggai, termasuk terkait efektivitas dalam mewujudkan pelestarian populasi, habitat, dan keanekaragaman genetik P. kauderni.

Tujuan penelitian adalah pengembangan suatu konsep konservasi berbasis kawasan yang tepat secara bioekologi maupun sosio-ekonomi. Hal ini didasarkan pada sifat bioekologis khas $P$. kauderni, khususnya: (i) stok yang terisolasi secara reproduktif dengan sifat genetik khas; (ii) ketergantungan tinggi terhadap habitat, khususnya simbiosisnya dengan organisme yang berperan sebagai mikro-habitat pelindung.

\section{METODOLOGI PENELITIAN}

Penelitian ini berupa kajian terhadap data dan informasi yang telah maupun belum dipublikasi dalam literatur ilmiah serta grey literature, cetak maupun elektronik, Data dianalisa secara deskriptif dan grafik, untuk menghasilkan sejumlah kesimpulan dan saran terkait dengan tujuan penelitian. Khusus Pulau Banggai, ditinjau kembali analisa spatial menggunakan spatial planning software MARXAN (Game \& Grantham, 2008; Ardon dkk., 2010) dalam ArcView 3.2 (Ndobe, 2013). Unit perencanaan berbentuk hexagon (segienam) lebar $100 \mathrm{~m}$ (areal $\pm 0.866 \mathrm{ha}$ ). FEATURES (sasaran konservasi, dengan persentase minimal yang hendak dilestarikan) dan COSTS (halhal yang dapat menghambat upaya konservasi sasaran tersebut) tercantum pada Tabel 1.

Hexagon 100\% daratan, daerah pelabuhan, Kota Banggai dan jalur pelayaran berstatus LOCKOUT (tidak dapat terpilih), sedangkan DPL (Daerah Perlindungan Laut) dan areal restorasi karang di Bone Baru berstatus LOCKIN (selalu terpilih). Sumber data adalah KLH (2007) (peta dasar, F1-3, C1, C3, C5) dan Ndobe (2013) (F4, C2, C4, modifikasi terhadap layar lainnya). Parameter Boundary Length Modifier (BLM) mewakili biaya berasosiasi dengan panjang batas KKP (Kawasan Konservasi Perairan), berpengaruh terhadap pola sebaran hexagon terseleksi sebagai calon/saran jejaring KKP oleh Marxan; diberi nilai 1 dan 0.1 .

\section{HASIL DAN DISKUSI}

3.1. Penentuan Unit Pengelolaan yang tepat - stok genetik P. kauderni

Kajian terhadap struktur genetika dan batas stok P. kauderni, umumnya menggunakan sejumlah mikrosatelit polimorfic yang ditemukan oleh Hoffman dkk. (2004), telah mengidentifikasi sedikitnya 21 sub-populasi dengan sifat genetik khas (Gambar 1) yang diduga sebagai stok terpisah secara reproduktif (Bernardi \& Vagelli, 2004; Hoffman dkk., 2005; Vagelli dkk., 2009; Ndobe, 2013).

Data genetika populasi yang tersedia (Bernardi \& Vagelli, 2004; Hoffman dkk., 2005; Vagelli dkk., 2009; Ndobe, 2013) baru yang mencakup 14 dari 34 pulau yang 
Tabel 1. FEATURES dan COSTS yang digunakan dalam analisa MARXAN

\begin{tabular}{|c|c|c|c|c|c|}
\hline No & FEATURE & TARGET & No & COST & Keterangan \\
\hline F1 & Mangrove & $20-35 \%$ & $\mathrm{C} 1$ & Desa & Radius 50-100m \\
\hline $\mathrm{F} 2$ & $\begin{array}{l}\text { Terumbu } \\
\text { karang }\end{array}$ & $20-35 \%$ & $\mathrm{C} 2$ & $\begin{array}{l}\text { Budidaya } \\
\text { rumput laut }\end{array}$ & Poligon \\
\hline F3 & $\begin{array}{l}\text { Padang } \\
\text { Lamun }\end{array}$ & $15-30 \%$ & $\mathrm{C} 3$ & Sungai & Radius sesuai ukuran \\
\hline \multirow{2}{*}{$\mathrm{F} 4$} & \multirow{2}{*}{$\begin{array}{l}\text { Populasi P. } \\
\text { kauderni }\end{array}$} & $\begin{array}{l}25-50 \% \text { dari } \\
\text { penyebaran }\end{array}$ & $\mathrm{C} 4$ & $\begin{array}{l}\text { Terbuka } \\
\text { pada cuaca }\end{array}$ & Poligon \\
\hline & & $\begin{array}{l}\text { setiap stok } \\
\text { genetika }\end{array}$ & $\mathrm{C} 5$ & Garis pesisir & $\begin{array}{l}\text { Hexagon dilalui oleh } \\
\text { garis pantai }\end{array}$ \\
\hline
\end{tabular}

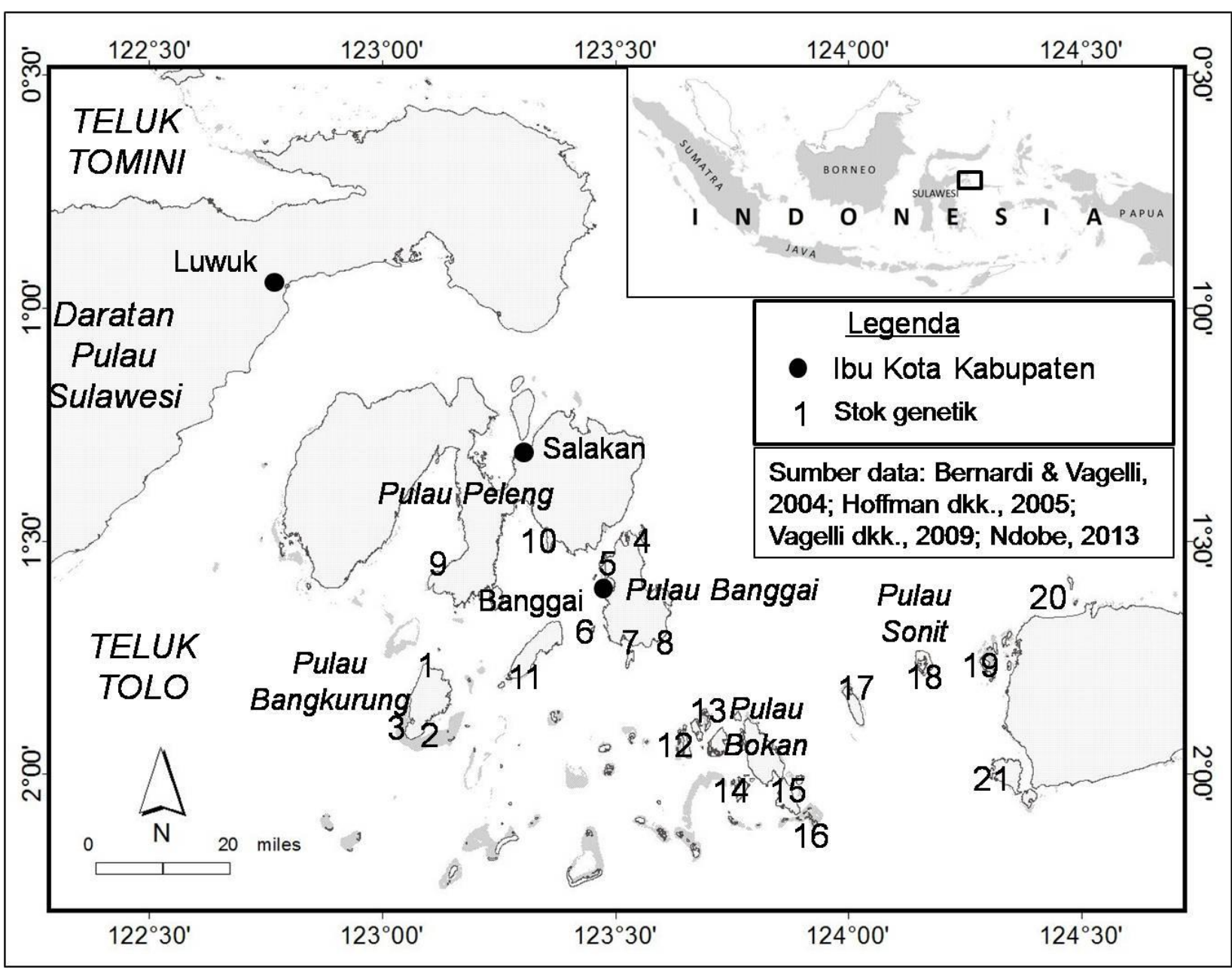

Gambar 1. Sub-populasi P. kauderni yang diketahui memiliki sifat genetik unik

menurut Vagelli (2011) memiliki populasi P. kauderni bersifat endemik. Namun demikian, secara keseluruhan data tersebut memberi indikasi kuat bahwa secara umum, sub-populasi di setiap pulau yang terisolasi oleh perairan relatif dalam (puluhan meter) merupakan stok genetik berbeda dengan pulau-pulau di sekitarnya. Kemudian, pada pulau-pulau lebih besar (seperti P. Banggai, P. Bangkurung dan P. 
Peleng) terdapat sejumlah sub-populasi yang terpisah secara reproduktif dan memiliki sifat genetik unik. Setiap subpopulasi tersebut dapat dipandang sebagai stok, masing-masing terpisah oleh perairan pesisir yang tidak tepat sebagai habitat $P$. kauderni, dengan jarak sekecil 2$5 \mathrm{~km}$ diantaranya.

Perbedaan genetik (genotipe) kerapkali terkait dengan perbedaan dalam morfologi atau yang nampak (fenotipe), sehingga penentuan batas stok ikan idealnya menggunakan data morfometrik dan genetik (Mobley dkk., 2011). Studi morfometrik (metode geometric morphometrics maupun morfometrik klasik) di Pulau Banggai menunjukkan bahwa terdapat perbedaan signifikan ( $\mathrm{p}<$ 0.05) dalam bentuk tubuh maupun sejumlah karakter morfometrik antar 5 sub-populasi atau stok dengan sifat genetik yang berbeda (Ndobe \& Moore, 2013c). Kemudian Vagelli (2011) mengemukakan hipotesa bahwa pola bintik putih pada tubuh $P$. kauderni bervariasi antar lokasi, mungkin terkait dengan perbedaan genetik antar sub-populasi (stok).

Sifat khas pada suatu stok mungkin berupa tanda plasticity atau kemampuan adaptasi fenotipe secara individu, ataupun perbedaan genetik (genotipe), disebabkan genetic drift dan faktor stokastik lainnya atau proses seleksi alam (Hellberg, 2009). Perbedaan genotipe/fenotipe khas dapat mempengaruhi fitness suatu individu, yaitu besarnya peluang reproduksi dan mewariskan genotipe (alel) pada generasi berikut (Pfaender dkk., 2010). Dengan demikian, unit pengelolaan biota laut seharusnya pada stok genetik (Palumbi, 2003; Rocha dkk., 2007). Merujuk pada prinsip kehati-hatian, keanekaragaman genetika perlu dijadikan pertimbangan penting dalam konservasi P. kauderni; khusunya, upaya pemulihan seharusnya menghindari pencampuran/perpindahan individu atau gamet $P$. kauderni antar sub- populasi yang diketahui atau diduga sebagai stok genetik.

\subsection{Mikrohabitat P. kauderni - khususnya Diadema sp.}

Menurut Vagelli (2011), Diadema setosum sebagai simbion utama $P$. kauderni. Data status dan pemanfaatan Diadema sp. maupun simbiosisnya dengan P. kauderni masih pada tingkat Genus. Data konektivitas dan sifat genetik Diadema sp., hal penting dalam konteks pelestarian/pemulihan populasi bulubabi dari genus tersebut, belum mencakup perairan Indonesia; namun spesies dari Genus Diadema dengan penyebaran luas di perairan Indopasifik mencakup pula Diadema savignyi (Lessios dkk., 2001). Hasil penelitian terbaru menunjukkan bahwa $P$. kauderni menggunakan $D$. setosum maupun D. savignyi sebagai mikrohabitat, baik di Kepulauan Banggai (Ndobe dkk., 2017) maupun di lokasi populasi introduksi $P$. kauderni di Kelurahan Mamboro, Teluk Palu (Moore dan Ndobe, data belum dipublikasi, Gambar 2).

\subsection{Analisa MARXAN di Pulau Banggai}

Unit (hexagon) terpilih oleh rumus iteratif MARXAN (BEST, warna ungu) sebagai prioritas untuk dimasukkan dalam kawasan konservasi ternyata cenderung relatif mirip antar ulangan apabila menggunakan parameter pengelolaan kawasan konservasi (terutama BLM) yang sama ataupun berbeda antar ulangan. Secara khusus, perairan sub-populasi (stok) P. kauderni di Lokotoy/Popisi, Bone Baru, Tolokibit dan Matanga/Kapela selalu terpilih, seperti pada contoh hasil ulangan RUN MARXAN representatif yang tercantum pada Gambar 3A. Pembesaran suatu lokasi (Teluk Matanga) tercantum pada Gambar 3B, dan menunjukkan areal paling sering terseleksi (warna merah) di teluk tersebut, yang serupa dengan lokasi 


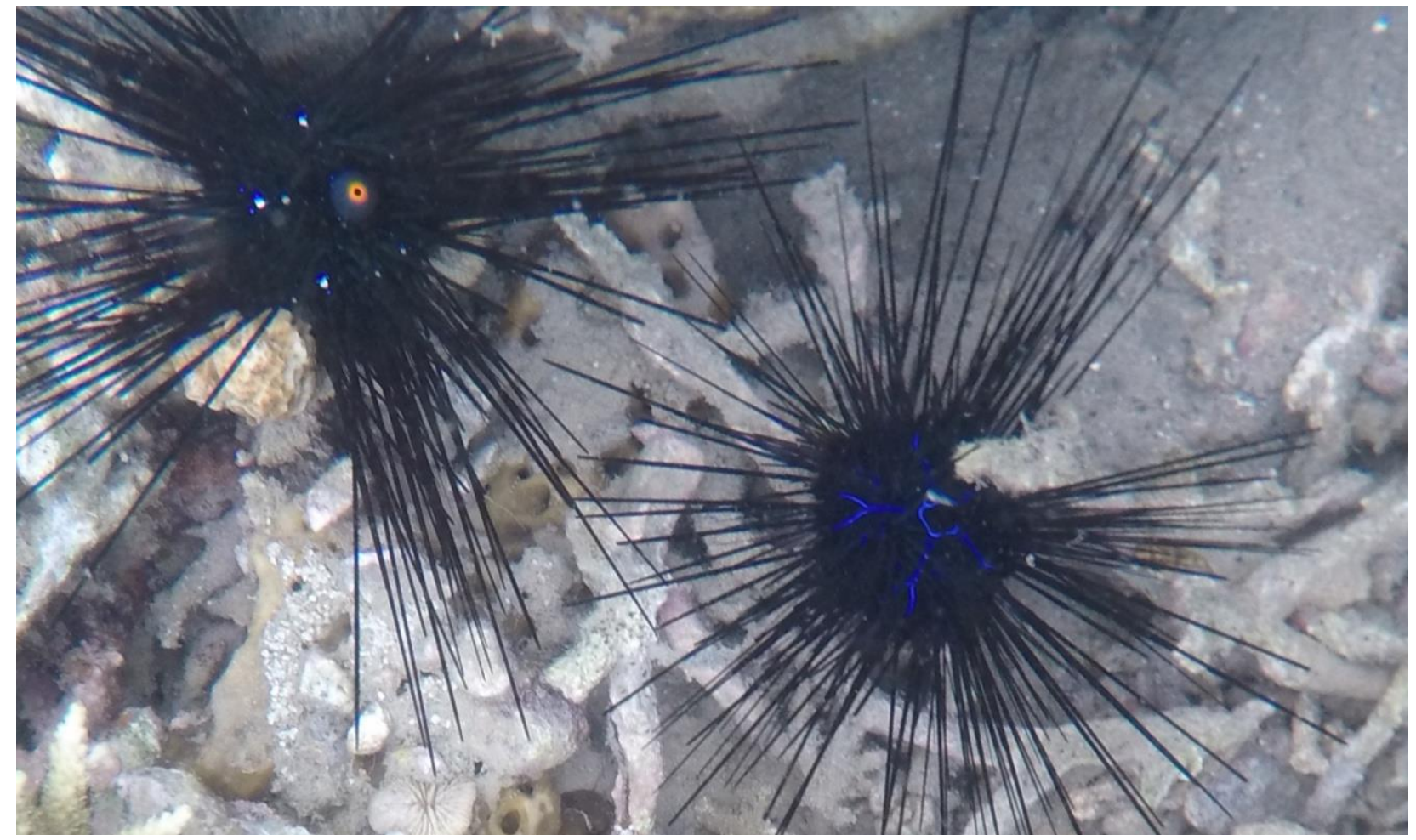

Gambar 2. D. setosum (kiri) dan D. savignyi (kanan) di habitat P. kauderni, Teluk Palu
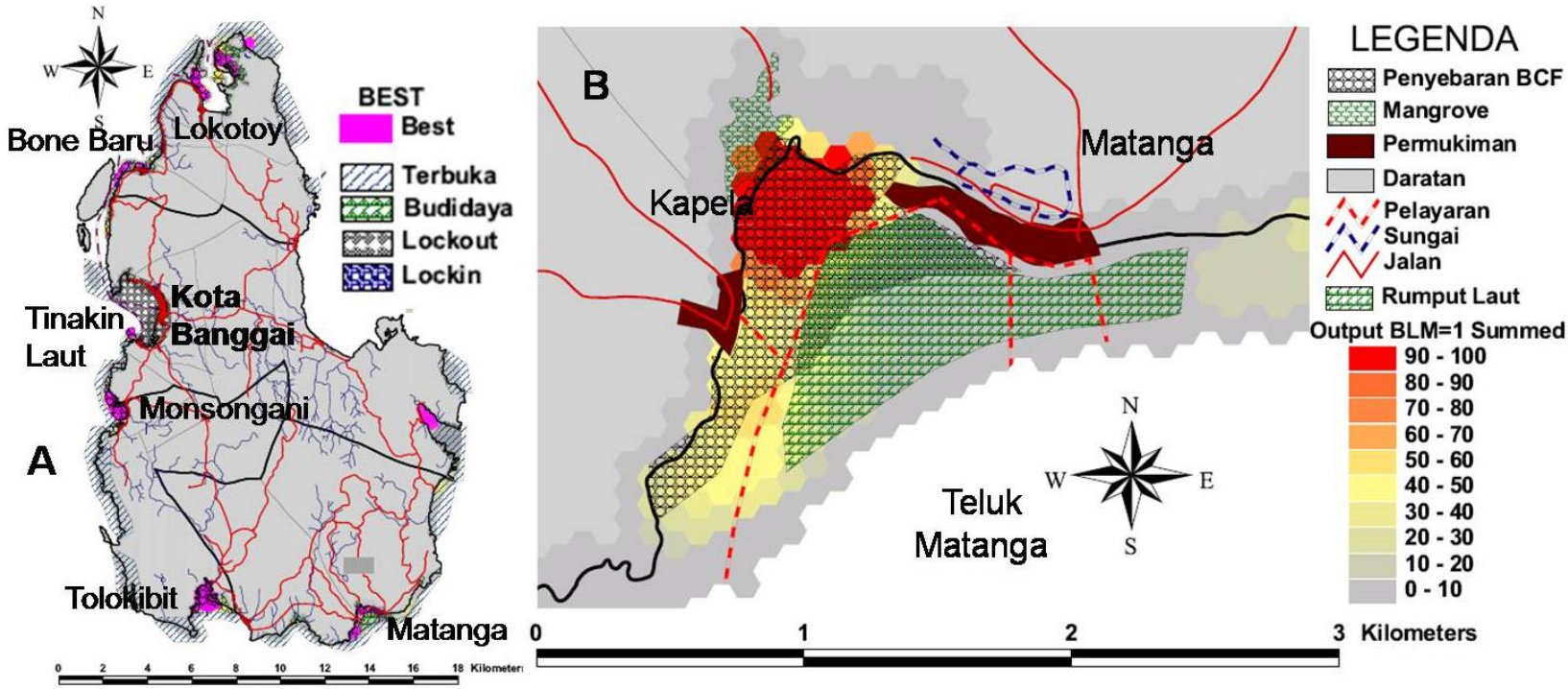

Gambar 3. Contoh peta hasil MARXAN: A. Pulu Banggai (hexagon SELECTED sebagai BEST ditandai dengan warna ungu); B. Teluk Matanga/Kapela (warna SUMMED menandai frekuensi - persentase -pemilihan hexagon pada RUN MARXAN dengan 1000 iterasi)

pemantauan Kapela tahun 2016 (Ndobe dkk., 2017). Di perairan tersebut, populasi maupun habitat $P$. kauderni dalam kondisi relatif baik, disebabkan upaya pencegahan kegiatan destruktif oleh masyarakat setempat sejak sekitar satu tahun sebelumnya. Database yang ada dapat diperbarui dan digunakan dalam perencanaan pada berbagai skala. 
Tabel 2. Isu kunci dan saran kebijkan maupun penelitian

\begin{tabular}{|c|c|c|c|}
\hline No. & Isu & Saran Kebijakan & Saran Penelitian \\
\hline 1 & $\begin{array}{l}\text { Struktur genetik } \\
\text { populasi endemik } \\
\text { P. kauderni }\end{array}$ & $\begin{array}{l}\text { Unit pengelolaan berbasis } \\
\text { kawasan= stok genetik } \\
\text { Menghindari aksi yang dapat } \\
\text { merubah sifat genetik stok, } \\
\text { termasuk gene flow non alami } \\
\text { (misalnya pada restocking) }\end{array}$ & $\begin{array}{l}\text { Riset (molekuler \& ekologi) } \\
\text { untuk menentukan jumlah } \\
\text { dan batas-batas stok genetik } \\
\text { Riset multi-disiplin untuk } \\
\text { menerangkan hubungan } \\
\text { spatial maupun temporal } \\
\text { antar stok }\end{array}$ \\
\hline 2 & $\begin{array}{l}\text { Degradasi habitat } \\
\text { khususnya } \\
\text { penurunan } \\
\text { drastis } \\
\text { kelimpahan } \\
\text { mikrohabitat }\end{array}$ & $\begin{array}{l}\text { Kebijakan pengendalian } \\
\text { pengelolaan perikanan } \\
\text { avertebrata bentik (bersifat } \\
\text { tak tercatat/tak } \\
\text { teratur/berlebih), khususnya } \\
\text { Diadema sp. dan anemon laut }\end{array}$ & $\begin{array}{l}\text { Riset multi-disiplin terhadap } \\
\text { mikrohabitat: sebaran dan } \\
\text { kelimpahan relatif spesies, } \\
\text { struktur genetik, konektivitas, } \\
\text { reproduksi, teknologi } \\
\text { budidaya, re-stocking }\end{array}$ \\
\hline 3 & $\begin{array}{l}\text { Pendekatan } \\
\text { holistik bio- } \\
\text { ekologi dan sosio- } \\
\text { ekonomi (a/l } \\
\text { paradigma EAFM) }\end{array}$ & $\begin{array}{l}\text { Pengembangan/penerapan } \\
\text { konsep "BCF gardens": } \\
\text { pemulihan populasi } P \text {. } \\
\text { kauderni melalui pemulihan } \\
\text { mikrohabitat pada skala kecil, } \\
\text { berbasis masyarakat }\end{array}$ & $\begin{array}{l}\text { Riset eksperimental terhadap } \\
\text { preferensi mikro-habitat pada } \\
\text { P. kauderni (semua } \\
\text { fase/umur) dan daya dukung } \\
\text { mikro-habitat } \\
\text { Uji-coba skala kecil konsep } \\
\text { "BCF gardens" ex-situ dan in- } \\
\text { situ }\end{array}$ \\
\hline
\end{tabular}

\subsection{Saran kebijakan KKPD dan penelitian pendukung}

Berdasarkan kajian di atas, tiga isu kunci teridentifikasi, dan sejumlah rekomendasi kebijakan tersusun, dalam konteks strategi efektif pengembangan KKPD, maupun penelitian lanjutan untuk mendukung pencapaian sasaran konservasi terkait populasi endemik $P$. kauderni. Isu dan saran tersebut secara ringkas pada Tabel 2 .

Konsep "BCF gardens" (Ndobe \& Moore, 2013b, Tabel 2) terinspirasi oleh gerakan Locally Managed Marine Areas (LMMA) yang lahir dikawasan Pasifik (Govan, 2009) dan telah mulai diterapkan di Indonesia (Steenbergen, 2013). Pendekatan pengelolaan lestari pada skala kampung/komunitas tersebut cenderung memanfaatkan adat/tradisi setempat, namun dapat pula mengembangkan "tradisi baru" yang disepakati masyarakat.
Sebuah kawasan LMMA umumnya dikelola untuk melestarikan dan meningkatkan sumberdaya/komoditas perikanan tertentu. Konsep BCF gardens, ditentukan kawasan relatif kecil di sebuah areal yang merukanan habitat P. kauderni; untuk medukung pemulihan populasi $P$. kauderni di dalam dan disekitar kawasan tersebut, upaya/sistem pengelolaan difokuskan pada pelestarian/pemulihan mikrohabitat (khususnya bulubabi, anemone laut, karang).

Konsep BCF gardens memerlukan dukungan dan partisipasi masyarakat, pemerintah, dan akademisi dengan keahlian khusus. Untuk mempertahakan keanekaragaman hayati (jenis, plasma nutfah), sebaiknya BCF garden terbentuk di sebaran setiap stok genetik P. kauderni. Penerapan konsep secara bertahap dapat dimulai dengan percontohan pada satu atau sejumlah kecil stok yang telah 
teridentifkasi, agar senantiasa berfungsi sebagai sarana riset dan pendidikan dalam penyempurnaan dan penyebarluasan konsep.

Beberapa faktor dinilai dapat mendukung keberhasilan penerapan konsep BCF Gardens, termasuk khususnya dalam konteks pengefektifan KKPD di Kapulauan Banggai. Antara lain, pola kehidupan sedentary P. kauderni maupun mikrohabitatnya; wewenang legislatif tingkat desa dalam paradigma Otonomi Daerah Indonesia dapat memberi pengakuan formal dan mendukung operasionalisasi pada skala kecil; partisipsi aktif masyarakat dalam beberapa upaya konservasi sebelumnya (Moore \& Ndobe, 2013).

\section{KESIMPULAN}

Data yang tersedia dinilai mencukupi untuk mengawali pendekatan berbasis stok (genetik) dalam konservasi $P$. kauderni secara umum, dan secara khusus dalam desain zona-zona spesifik perlindungan $P$. kauderni di Kawasan Konservasi Perairan Daerah (KKPD) di Kepulauan Banggai, Provinsi Sulawesi Tengah. Namun demikian, masih penting melanjutkan proses identifikasi sub-unit (stock) P. kauderni dan batas-batas diantaranya, maupun meningkatkan pengetahuan mengenai simbion $P$. kauderni, peran dan pemulihan populasinya melalui berbagai kajian multidisiplin. Pola konservasi khusus yang ditawarkan adalah konsep "BCF gardens": pelestarian $P$. kauderni melalui pemulihan mikrohabitat pada skala kecil, berbasis masyarakat, didukung oleh program riset ilmiah.

\section{UCAPAN TERIMAKASIH}

Penulis mengucapkan terima kasih kepada semua pihak yang telah memberi dukungan dalam bentuk apapun sehingga penelitian telah terlaksana dan artikel (makalah) ini tersusun.

\section{DAFTAR PUSTAKA}

Allen, G.R. 2000. Threatened fishes of the world: Pterapogon kauderni Koumans, 1933 (Apogonidae). Environmental Biology of Fishes 57, 142

Allen, G.R, Donaldson, T.J. 2007. Pterapogon kauderni. The IUCN Red List of Threatened Species 2007. (accessed 21/01/17) http://dx.doi.org/10.2305/IUCN.UK. 2007.RLTS.T63572A12692964.en

Ardron J.A., Possingham H.P., Klein C.J. (Eds.). 2010. Marxan Good Practices Handbook, Version 2. Pacific Marine Analysis and Research Association, Victoria. 165 pp.

Bernardi, G., Vagelli, A. 2004. Population structure in Banggai cardinalfish, Pterapogon kauderni, a coral reef species lacking a pelagic larval phase. Marine Biology 145, 803-810

Game, E.T., Grantham, H.S. 2008. Marxan User Manual: For Marxan version 1.8.10. University of Queensland, Australia, and Pacific Marine Analysis and Research Association, Vancouver. $135 \mathrm{pp}$.

Govan, H. 2009. Status and potential of locally-managed marine areas in the South Pacific: meeting nature conservation and sustainable livelihood targets through widespread implementation of LMMAs. SPREP/WWF/WorldFishReefbase/CRISP. 95pp

Hellberg, M.E.. 2009. Gene Flow and Isolation among Populations of Marine Animals. Annual Review of Ecology, Evolution, and Systematics 40, 291-310

Hoffman, E.A., Arguello, J.R., Kolm, N., 
Berglund, A., Jones, A.G. 2004. Eleven polymorphic microsatellite loci in a coral reef fish, Pterapogon kauderni. Molecular Ecology Notes 2004(4), 342-344

Hoffman, E.A., Kolm, N., Berglund, A., Arguello, J.R, Jones, A.G. 2005. Genetic structure in the coral-reef-associated Banggai cardinalfish, Pterapogon kauderni. Molecular Ecology 14, 1367-1375

KLH. 2007. BANGKEP_New. Sebuah proyek ArcView 3.x Kabupaten Banggai Kepulauan berdasarkan Peta Rupa Bumi Indonesia skala 1:50,000, Citra Landsat TM Path/Row 112/61 Tahun 2003 dan kerja lapangan Mei-Juni 2007. Diperoleh dari Badan Lingkungan Hidup Kabupaten Banggai Kepulauan pada tahun 2009.

Lessios, A.H.A., Kessing, B.D., Pearse, J.S. 2001. population structure and speciation in tropical seas : global phylogeography of the sea urchin Diadema. Evolution 55(5), 955-975

Mobley, K.B., Lussetti, D., Johansson, F., Englund, G., Bokma, F. 2011. Morphological and genetic divergence in Swedish postglacial stickleback Pungitius pungitius populations. BMC Evolutionary Biology 11, 287

Moore, A., Ndobe, S. 2013. The Banggai cardinalfish: An overview of management and conservation initiatives. Galaxea, Journal of Coral Reef Studies 2013(SI), 238-242

Moore, A., Ndobe, S., Salanggon, A.I.M, Ederyan, Rahman, A. 2012. Banggai Cardinalfish Ornamental Fishery: The Importance of Microhabitat. Proceedings of the 12th International Coral Reef Symposium, Cairns, Australia, 9-13 July 2012, 13C_1. http://www.icrs2012.com/proceedi ngs/manuscripts/ICRS2012_13C_1.p df
Moore, A., Ndobe, S., Jompa, J. 2017. Fingerprints of the Anthropocene: the 2016 Coral Bleaching Event in an Equatorial Archipelago. Proceedings of the 4th International Marine and Fisheries Symposium, Makassar, 20 May 2017, 66-86

Ndobe, S. 2013. Biologi dan Ekologi Banggai Cardinalfish, Pterapogon kauderni (Suatu Kajian Dalam Upaya Pengelolaan Perikanan Berbasis Konservasi. Disertasi. Program Pascasarjana, Universitas Brawijaya, Malang, Indonesia.

Ndobe, S., Madinawati, Moore, A. 2008 Pengkajian Ontogenetic Shift pada Ikan Endemik Pterapogon kauderni. Jurnal Mitra Bahari 22, 32-55

Ndobe, S., Setyohadi, D., Herawati, E.Y., Soemarno, Moore, A., Palomares, M.D., Pauly D. 2013a. Life History of Banggai Cardinalfish Pterapogon kauderni (Actinopterygii: Pisces: Apogonidae) in Banggai Islands and Palu Bay, Sulawesi, Indonesia. Acta Ichthyologica Et Piscatoria 433, 237250

Ndobe, S.; Moore, A., Salanggon, A.I.M., Muslihudin, Setyohadi, D., Herawati, E.Y., Soemarno. 2013b. Pengelolaan Banggai cardinalfish Pterapogon kauderni melalui Konsep EcosystemBased Approach. Marine Fisheries 2013(2), 115-126

Ndobe, S. \& Moore, A. 2013c. Banggai cardinalfish (Pterapogon kauderni) populations (stocks) around Banggai Island, a geometric and classical morphometric approach. PeerJ PrePrints, e182v1. https://peerj.com/preprints/182v1. pdf (accessed 15/01/17)

Ndobe, S. Widiastuti, I., Moore, A. 2013d. Sex ratio dan Pemangsaan terhadap Rekrut pada Ikan Hias Banggai Cardinalfish Pterapogon kauderni. Prosiding Konferensi Akuakultur 
Indonesia

2013.

http://epaper.aquaculture-

mai.org/upload/2.\%20Ndobe\%20dk

k \%20KAI\%202013.pdf (accessed $27 / 04 / 15)$

Ndobe, S., Moore, A., Nasmia, Madinawati, Serdiati, N. 2013e. The Banggai cardinalfish: an overview of local research 2007-2009. Galaxea, Journal of Coral Reef Studies 2013(SI), 243252

Ndobe, S., Moore, A., Jompa, J. 2017. Status dan Ancaman terhadap Mikrohabitat Ikan Endemik Terancam Punah Banggai Cardinalfish (Pterapogon kauderni). Coastal and Ocean Journal Vol. 1 (2): 73-82.

Palumbi, S.R. 2003. Population Genetics, Demographic Connectivity, and the Design of Marine Reserves. Ecological Applications 131, S146-S158

Pfaender, J., Schliewen, U.K., Herder, F. 2010. Phenotypic traits meet patterns of resource use in the radiation of "sharpfin" sailfin silverside fish in Lake Matano. Evolutionary Ecology 24(5), 957974

Rocha, L.A., Craig, M.T., Bowen, B.W. 2007.
Phylogeography and the conservation of coral reef fishes. Coral Reefs 26(3), 501-512

Steenbergen, D.J. 2013. Negotiating the Future of Local "Backwaters": Participatory Marine Conservation on Small Islands in Eastern Indonesia. PhD Thesis, Murdoch University. 366 pp. (accessed 13/12/16)

Http://researchrepository.murdoch. edu.au/19364/2/02Whole.pdf

Talbot, R., Pedersen, M., Wittenrich, M.L., \& Moe Jr, M. 2013. Banggai cardinalfish: a guide to captive care, breeding. \& natural history. Reef to Rainforest Media, Shelburne. 159 pp.

Vagelli A.A., Burford M., Bernardi G. 2009. Fine scale dispersal in Banggai Cardinalfish, Pterapogon kauderni, a coral reef species lacking a pelagic larval phase. Marine Genomics 1, 129-134

Vagelli, A.A. 2011. The Banggai Cardinalfish: Natural History, Conservation, and Culture of Pterapogon kauderni. John Wiley \& Sons, Ltd., Chichester. 219 pp. 